\title{
KLASTERISASI PENYAKIT MENGGUNAKAN ALGORITMA K-MEDOIDS PADA DINAS KESEHATAN KABUPATEN AGAM PROVINSI SUMATERA BARAT
}

\author{
Minarni ${ }^{1}$, Elsa Indah Sari ${ }^{2}$, Anna Syahrani ${ }^{3}$, Putri Mandarani ${ }^{2}$ \\ ${ }^{1.2 .3}$ Teknik Informatika, Institut Teknologi Padang, Indonesia \\ e-mail: minarni1706@gmail.com ${ }^{1}$, elsaindahsari5@gmail.com ${ }^{2}$, \\ annasyahrani@gmail.com ${ }^{3}$, pmandarani2@gmail.com ${ }^{4}$
}

\begin{abstract}
Abstrak
Jumlah kasus penyebaran penyakit tuberculosis (TB), pneumonia, dan demam berdarah dengue (DBD) pada Dinas Kesehatan Kabupaten Agam setiap tahun mengalami peningkatan. Kondisi alam kabupaten Agam dengan wilayah yang luas dan perbukitan menyebabkan sulitnya memantau penyebaran penyakit berdasarkan kasus terbanyak. Hal ini menyebabkan lambatnya pencegahan maupun penanggulangan penyakit tersebut. Untuk itu diperlukan cara pengelompokkan atau klasterisasi penyakit berdasarkan jumlah kasus yang banyak terjadi. Penelitian ini bertujuan untuk menerapkan algoritma K-Medoids untuk pengelompokkan data penyakit berdasarkan jumlah kasus. Algoritma ini merupakan metode klasterisasi pembatas untuk mengelompokkan sekumpulan $\mathrm{n}$ objek menjadi beberapa $\mathrm{k}$ klaster. Data yang digunakan berupa data penderita penyakit DBD, TB, dan pneumonia dari tahun 2016-2019 sebanyak 370 record. Hasil pengujian diperoleh anggota masing-masing klaster untuk tiap-tiap penyakit yaitu tuberculosis klaster tinggi 32 dan rendah 60, penyakit pneumonia klaster tinggi 33 dan rendah 59, sedangkan untuk penyakit DBD klaster tinggi 10 anggota dan rendah 82 anggota. Pengujian menggunakan perhitungan manual dan aplikasi Rapidminer mendapatkan hasil yang sama dengan sistem. Ini menunjukkan bahwa sistem telah bekerja dengan baik.
\end{abstract}

Kata kunci: Algoritma K-Medoids, Klasterisasi, Penyakit

\begin{abstract}
The number of cases of tuberculosis (TB), pneumonia, and dengue fever (DBD) at the Agam District Health Office has increased every year. The Agam Regency with its wide area and hills makes it difficult to monitor the spread of the disease. This causes prevention and response to be delayed. For that, it is necessary to group or cluster diseases based on cases. The purpose of this study is to apply the KMedoids algorithm for grouping disease data. This algorithm is a constraint clustering method to group a set of $n$ objects into several $k$ clusters. The data used are data on patients with dengue fever, TB, and pneumonia from 2016-2019 as many as 370 records. The test results obtained members of each cluster for each disease, namely tuberculosis cluster high 32 and low 60, pneumonia disease cluster high 33 and low 59, while for high cluster DBD 10 members and low 82 members. Tests using manual calculations and the Rapidminer application get the same results as the system. This indicates that the system is working properly.
\end{abstract}

Keywords : K-Medoids Algorithm, Clustering, disease

Diterima Redaksi: 17-6-2021 | Selesai Revisi: 20-10-2021 | Diterbitkan Online: 31-12-2021 DOI: https://doi.org/10.23887/janapati.v10i3.34904

\section{PENDAHULUAN}

Kabupaten Agam mempunyai luas $2.232,30 \mathrm{Km}^{2}$ atau $5,29 \%$ dari seluruh wilayah Provinsi Sumatera Barat. Kabupaten Agam mempunyai 16 Kecamatan dan 82 Nagari serta 467 Jorong. Jumlah penduduk Kabupaten Agam berdasarkan data BPS tahun 2018 sebanyak 487.914 jiwa[1]. Dinas Kesehatan Kabupaten
Agam merupakan unsur pemerintah Kabupaten yang bertanggung jawab dalam bidang kesehatan meliputi kesehatan masyarakat, pencegahan dan pengendalian penyakit, pelayanan, dan sumber daya kesehatan. Dinas Kesehatan Kabupaten Agam memiliki 23 puskesmas dan 2 rumah sakit yang tersebar di 16 Kecamatan di wilayah Kabupaten Agam. 
Berdasarkan data Dinas Kesehatan Kabupaten Agam tahun 2016-2019, jumlah kasus penyebaran penyakit tuberculosis (TB), pneumonia, dan demam berdarah dengue (DBD) mengalami peningkatan. Dengan wilayah yang luas dan kondisi alam perbukitan menyebabkan Dinas Kesehatan Kabupaten Agam sulit untuk memantau penyebaran penyakit dengan jumlah kasus terbanyak. Hal ini menyebabkan lambatnya pencegahan maupun penanggulangan penyakit tersebut. Untuk itu diperlukan cara pengelompokkan atau klasterisasi penyakit berdasarkan jumlah kasus yang banyak terjadi.
Data mining menjadi salah satu pilihan untuk menyelesaikan masalah pengelompokkan data, karena data mining merupakan proses untuk menemukan pola baru dari sekumpulan data yang sangat besar [2]. Hasil dari proses ini dapat digunakan dalam menentukan keputusan. Di dalam data mining terdapat metode yang digunakan untuk menemukan pola atau pengetahuan baru dikenal dengan Knowledge Discovery In Database (KDD) [3]. Proses KDD seperti pada gambar 1.

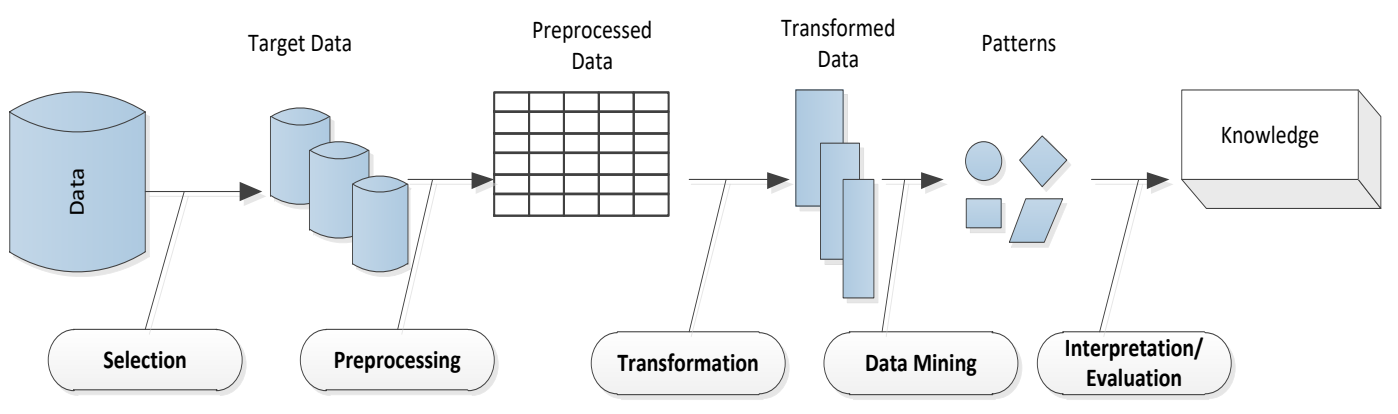

Gambar 1. Proses Penemuan Pengetahuan dalam Database (KDD)

berikut:

Proses di atas dapat dijelaskan sebagai

a. Selection

Selection merupakan langkah awal dalam menentukan variabel yang akan digunakan tidak memiliki kemiripan dan duplikasi.

b. Preprocessing

Pra pengolahan (preprocessing) data yang terdiri dari data cleaning dan data integration.

c. Tranformation

Transformasi merupakan proses merubah data menyesuaikan dengan format ekstensi yang diperlukan pada pengolahan data mining.

d. Data mining merupakan proses yang utama untuk mendapatkan pengetahuan baru dari data yang diproses, salah satunya Clustering[4]. Clustering atau klasterisasi digunakan untuk mengelompokkan data-data ke dalam beberapa kelompok berdasarkan tingkat kemiripan[5]. Dengan tujuan untuk membagi objek (orang, benda, peristiwa, dan lain-lain) ke dalam suatu kelompok, sehingga objek-objek dalam satu kelompok (klaster) memiliki kesamaan yang tinggi namun memiliki perbedaan dengan objek pada kelompok lainnya [6].
Salah satu algoritma clustering yang digunakan yaitu algoritma k-medoids. Algoritma ini merupakan pengembangan dari algoritma k-Means yang bertujuan untuk mengurangi tingkat kepekaan pada bagian yang dihasilkan berkaitan dengan nilai-nilai yang terdapat dalam kumpulan data, dimana memungkinkan adanya penyimpangan distribusi data disebabkan oleh objek dengan nilai yang besar [7]. Algoritma ini merupakan metode klasterisasi partisi untuk mengelompokkan sekumpulan $\mathrm{n}$ objek menjadi beberapa k klaster. Objek yang berada pada kumpulan objek mewakili sebuah klasternya, dikenal dengan medoid. Kemudian klaster dihitung dengan cara menghitung kedekatan antara medoid dengan objek non medoid. Medoids digunakan tidak berdasarkan dari pengamatan nilai rata-rata (mean) yang dimiliki oleh setiap kelompok [8].

e. Interpretasi merupakan proses mengidentifikasi pola-pola yang unik ke dalam basis pengetahuan yang diidentifikasi. 
Beberapa penelitian tentang penerapan algoritma k-medoids dalam bidang kesehatan telah dilakukan diantaranya pengelompokkan penyebaran diare [5]. Penelitian ini menghasilkan pengelompokkan wilayah di Kota Medan menjadi dua klaster berdasarkan jumlah penderita diare. Selanjutnya penelitian klasterisasi data penyakit pasien di RSUD Kota Bandung [9]. Penelitian ini membahas tentang pengelompokan penyakit yang diderita pasien dikelompokkan menjadi 3 klaster berdasarkan kamar dan jumlah pasien, yaitu klaster 0 untuk penyakit pada klinik gawat darurat sebanyak 18 data, klaster 1 untuk penyakit pada klinik kemuning dan klinik gawat darurat, dan klaster 3 untuk klinik rehab medik sebanyak 20 data.

$$
\text { Penelitian berikutnya tentang }
$$

pengelompokan kasus penyakit AIDS berdasarkan provinsi [10]. Penelitian ini mengelompokkan kasus penyakit AIDS menjadi dua klaster berdasarkan parameter rata-rata jumlah kasus yang terjadi dan rata-rata jumlah kasus penyakit AIDS yang meninggal. Penelitian untuk pengelompokan penyakit di Pekanbaru Riau [11]. Penelitian ini membahas tentang penyebaran penyakit yang paling banyak diderita dengan cara mengelompokkan menjadi 4 klaster. Penelitian lainnya pengelompokan data imunisasi campak balita di Indonesia [12]. Penelitian ini membahas tentang pengelompokan data imunisasi campak balita, dengan mengelompokkan data imunisasi menjadi 3 klaster, yaitu rendah, sedang, dan tinggi. Penelitian clustering pasien kanker berdasarkan struktur protein dalam tubuh [7], yang membahas tentang pengelompokan jenis kanker berdasarkan kelasnya, Hasil penelitian ini adalah sebuah sistem pengelompokan jenis kanker, dengan nilai persentase kualitas klaster sebesar $77 \%$ pada percobaan nilai k 14 menggunakan 116 data.

Penelitian tentang pengelompokkan data penyakit alergi pada anak dengan mengimplementasikan algoritma k-Medoids membagi klaster menjadi 3 , yaitu rendah 21 provinsi, sedang 12 provinsi, dan 1 provinsi untuk klaster tinggi [13]. Penelitian tentang pengelompokkan penyebaran covid-19 di Indonesia berdasarkan gejala suhu badan di atas $36,9^{\circ} \mathrm{C}$, demam, dan batuk, menghasilkan 3 klaster [14]. Penelitian tentang pengelompokkan data pasien kardiovaskuler menggunakan k-Medoids dengan kombinasi teknik reduksi data dengan PCA berdasarkan tingkat komplikasi pasien pada setiap cluster data yang dihasilkan [15]. Penelitian tentang pengelompokkan wilayah sebaran cacat pada anak, mendapatkan hasil bahwa algoritma k- medoids lebih baik dalam mengelompokkan dibandingkan dengan algoritma k-means [16]. Selanjutnya pengelompokan imunisasi lanjutan pada anak usia 2 tahun dengan hasil 3 klaster [17].

Penelitian ini bertujuan untuk menerapkan algoritma k-Medoids untuk pengelompokkan data penyakit berdasarkan jumlah kasus pada Dinas Kesehatan Kabupaten Agam. Output yang dihasilkan berupa kelompok atau klaster jumlah kasus tinggi dan rendah untuk penyakit demam berdarah, tuberculosis, dan pneumonia. Hasil pengelompokkan klaster penyakit dapat digunakan sebagai bahan pertimbangan dalam mengambil kebijakan untuk pencegahan dan penanggulangan penyakit pada Dinas Kesehatan Kabupaten Agam.

\section{METODE}

Penelitian ini dilaksanakan berdasarkan tahapan yang ditampilkan pada gambar 2 .

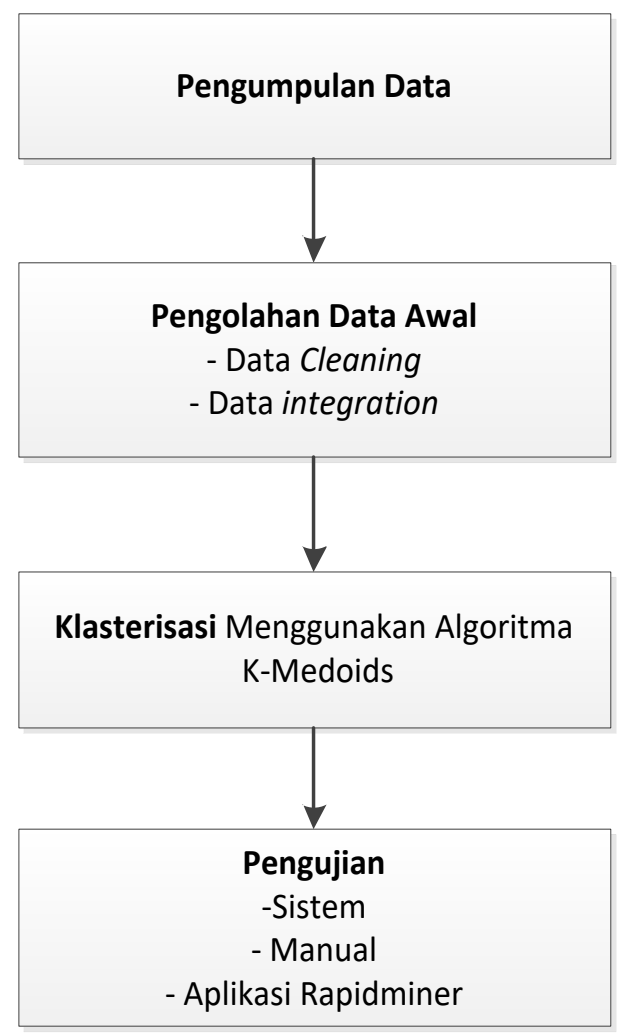

Gambar 2. Tahapan Penelitian

Tahapan-tahapan tersebut dapat dijelaskan sebagai berikut.

1. Pengumpulan Data

Penelitian ini menggunakan data dari Dinas Kesehatan Kabupaten Agam tahun 2016- 
2019, berupa data jumlah kasus tuberculosis (TB), demam berdarah dengue (DBD), dan pneumonia.

2. Pengolahan Data Awal

Pengolahan data awal dimulai dengan tahapan pembersihan data (cleaning data) dan proses integrasi yang bertujuan untuk menghilangkan nilai-nilai yang keliru atau tidak terisi, duplikasi data, serta memperbaiki data yang tidak konsisten. Data set yang didapatkan adalah sebanyak 370 data penyebaran penyakit. Dari data penyakit yang mempunyai field seperti no, kecamatan, puskesmas, sesuai standar, tidak sesuai standar,jumlah pelayanan, lakilaki, perempuan, total kasus, tuberculosis anak, jumlah kasus, lintang, bujur dan tahun. Setelah melakukan proses pembersihan data maka data set yang di dapat adalah 368 record. Kemudian proses selection, dimana proses ini memilih sampling data yang akan digunakan sebanyak 368 record, yang awalnya 370 record, ini disebabkan karena ada 2 data yang nilai dan valuenya tidak konsisten. Data yang digunakan berupa data puskesmas, kecamatan, dan jumlah kasus pada penyakit. Hasil cleaning dapat dilihat pada tabel 1.

Tabel 1. Hasil Cleaning Data Penyakit DBD

\begin{tabular}{cllcc}
\hline No & Kecamatan & Puskesmas & Kasus & Tahun \\
\hline 1 & Baso & Baso & 28 & 2019 \\
\hline 2 & Baso & $\begin{array}{l}\text { Padang } \\
\text { Tarok }\end{array}$ & 9 & 2019 \\
\hline 3 & $\begin{array}{l}\text { Ampek } \\
\text { Angkek }\end{array}$ & Biaro & 6 & 2019 \\
\hline$\ldots$ & $\ldots \ldots$ & $\ldots \ldots$ & $\ldots$ & $\ldots$ \\
\hline$\ldots$ & $\ldots \ldots$ & $\ldots \ldots$ & $\ldots$ & $\ldots$ \\
\hline 91 & Tanjung & Tiku & 0 & 2016 \\
\hline
\end{tabular}

\begin{tabular}{|c|c|c|c|c|}
\hline & Mutiara & & & \\
\hline 92 & $\begin{array}{l}\text { Tanjung } \\
\text { Mutiara }\end{array}$ & $\begin{array}{l}\text { Muaro } \\
\text { Putuih }\end{array}$ & 2 & 2016 \\
\hline
\end{tabular}

3. Klasterisasi Menggunakan Algoritma KMedoids

Langkah-langkah pengelompokkan atau klasterisasi penyakit pada gambar 3 [12],

a. Menentukan Jumlah Klaster (k)

Metode yang digunakan untuk menentukan jumlah klaster yaitu Metode Elbow. Metode ini mempertimbangkan nilai perbandingan Sum of Square Error (SSE) untuk setiap nilai klasternya. Tujuan dari metode elbow adalah untuk memilih nilai $\mathrm{k}$ yang kecil dan masih memiliki SSE yang rendah [18].

SSE dihitung menggunakan rumus berikut:

$$
S S E=\sum_{k=1}^{k} \sum_{x i}\left|x_{i}-c_{k}\right|
$$

b. Menentukan pusat klaster yang dipilih secara acak.

c. Menghitung Euclidean Distance menggunakan rumus berikut.

$$
d(x, y)=\|x-y\|=\sqrt{\sum_{i=1}^{n}\left(x_{i}-y_{i}\right)^{2}}
$$

d. Menentukan pusat klaster baru secara acak dan dilanjutkan menghitung Euclidean Distance.

e. Menghitung Total Simpangan (S) yaitu selisih total cost baru dengan total cost lama. Jika $S<0$, lakukan langkah b sampai e. Dan jika $\mathrm{S}>0$ maka ditemukan hasil klasterisasi. 


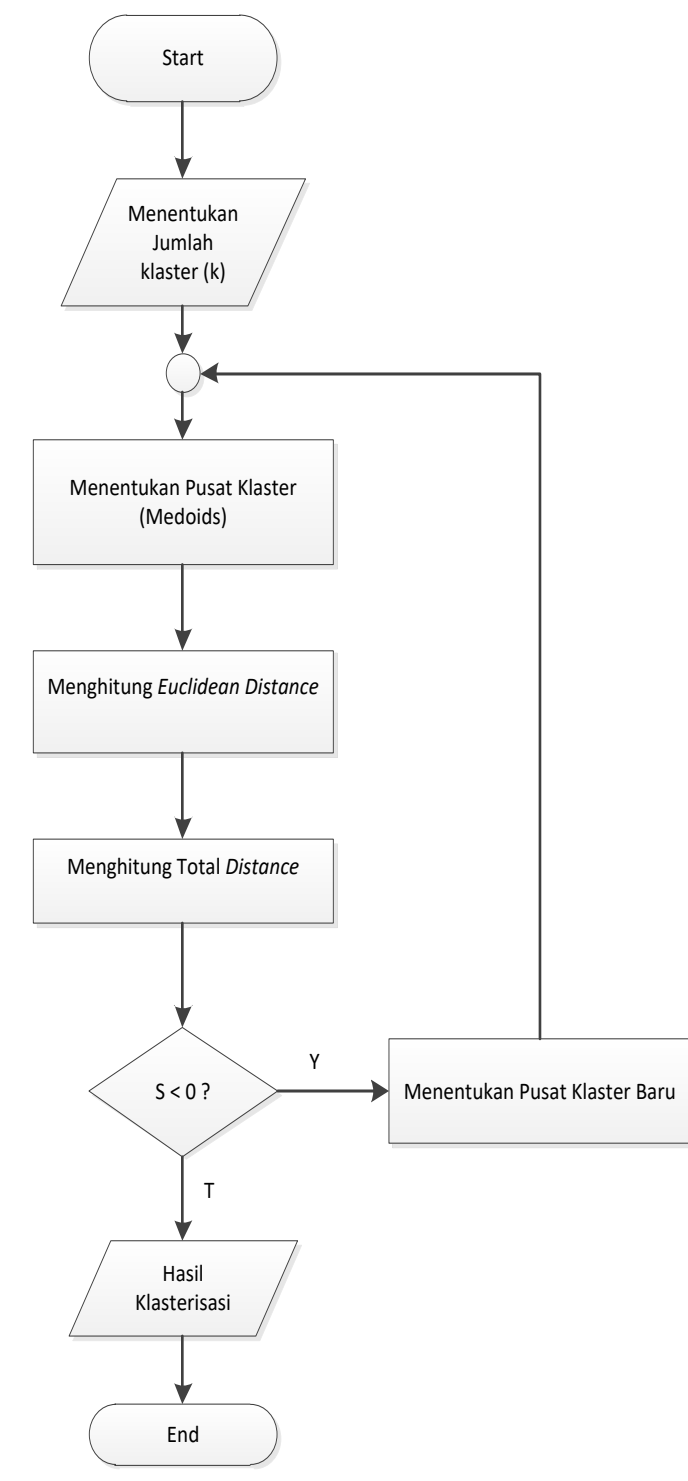

Gambar 3. Flowchart Algoritma K-Medoids

Halaman utama sistem terdiri dari 4 menu, yaitu menu home yang akan menampilkan informasi hasil cluster dan gambaran penyebarannya. Kemudian menu data, di mana menu ini memiliki sub menu, yaitu

\section{Pengujian}

Pada tahapan ini, pengujian klasterisasi penyakit dilakukan dengan menggunakan sistem yang dibangun, perhitungan secara manual, dan menggunakan aplikasi Rapidminer. Aplikasi ini merupakan salah satu tools untuk melakukan analisis terhadap data mining, text mining, dan analisis prediksi [17]. Pengujian bertujuan untuk mengetahui hasil kinerja klasterisasi dari sistem yang dibangun.

\section{HASIL DAN PEMBAHASAN}

Klasterisasi penyakit dengan menerapkan Algoritma K-Medoids dibangun dengan bahasa pemrograman PHP dan basis data MYSQL. Data penyakit yang digunakan tuberculosis, demam berdarah, dan pneumonia. Parameter klasterisasi ini berupa nama puskesmas, kecamatan, jumlah kasus. Proses klasterisasi digunakan untuk mengetahui pola sebaran penderita penyakit pada suatu daerah.Tampilan halaman utama sistem dapat dilihat pada gambar 4 .
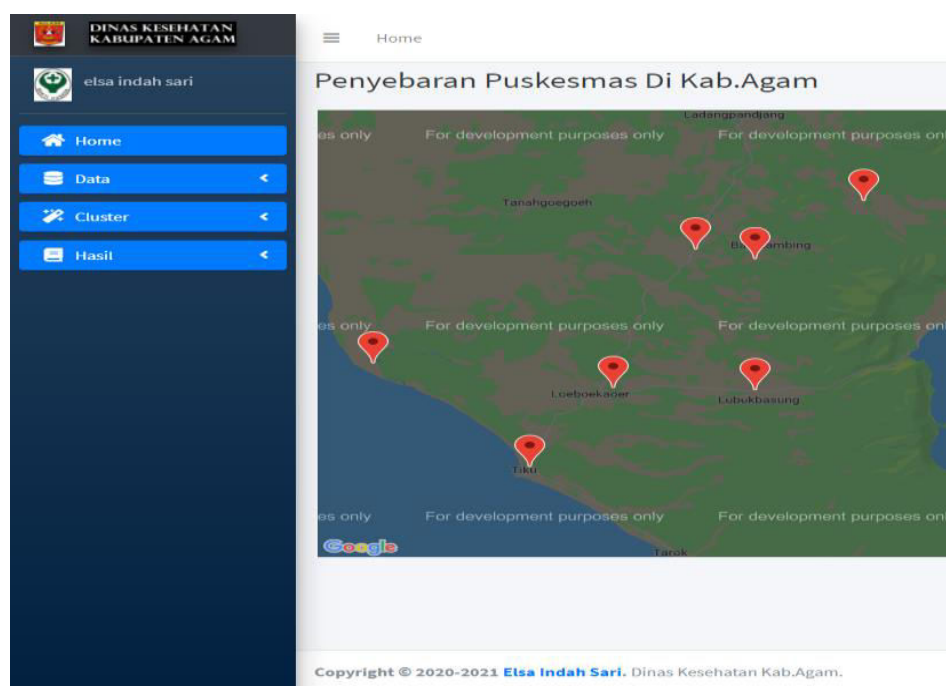

Gambar 4. Halaman Utama Klasterisasi Penyakit

user, lokasi, tuberculosis, DBD, dan pneumonia. Kemudian menu cluster, dimana pada menu ini proses klasterisasi menggunakan algoritma KMedoids. Menu hasil terdapat sub menu laporan jenis penyakit berdasarkan tahun yang ada.

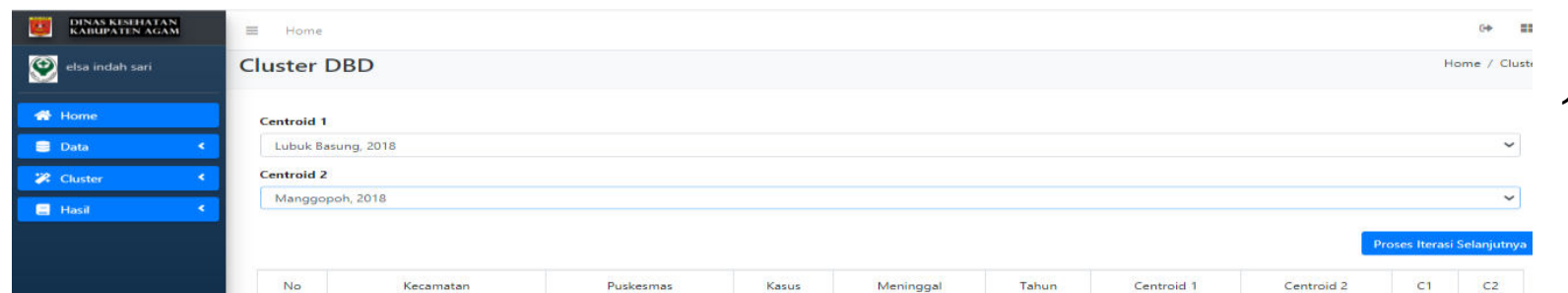


Proses klasterisasi dengan algoritma KMedoids pada menu cluster ditampilkan pada gambar 5. Untuk memulai user harus memilih salah satu jenis penyakit yang akan dikelompokkan. Kemudian memilih 2 buah pusat klaster secara acak atau centroid 1 dan centroid 2.
Kemudian menekan tombol proses iterasi selanjutnya. Iterasi akan berhenti jika nilai simpangannya besar dari 0 . Hasil klasterisasi ditunjukkan pada gambar 6 . Di sini terlihat klaster rendah ditandai dengan kotak warna biru dan klaster tinggi dengan warna merah.

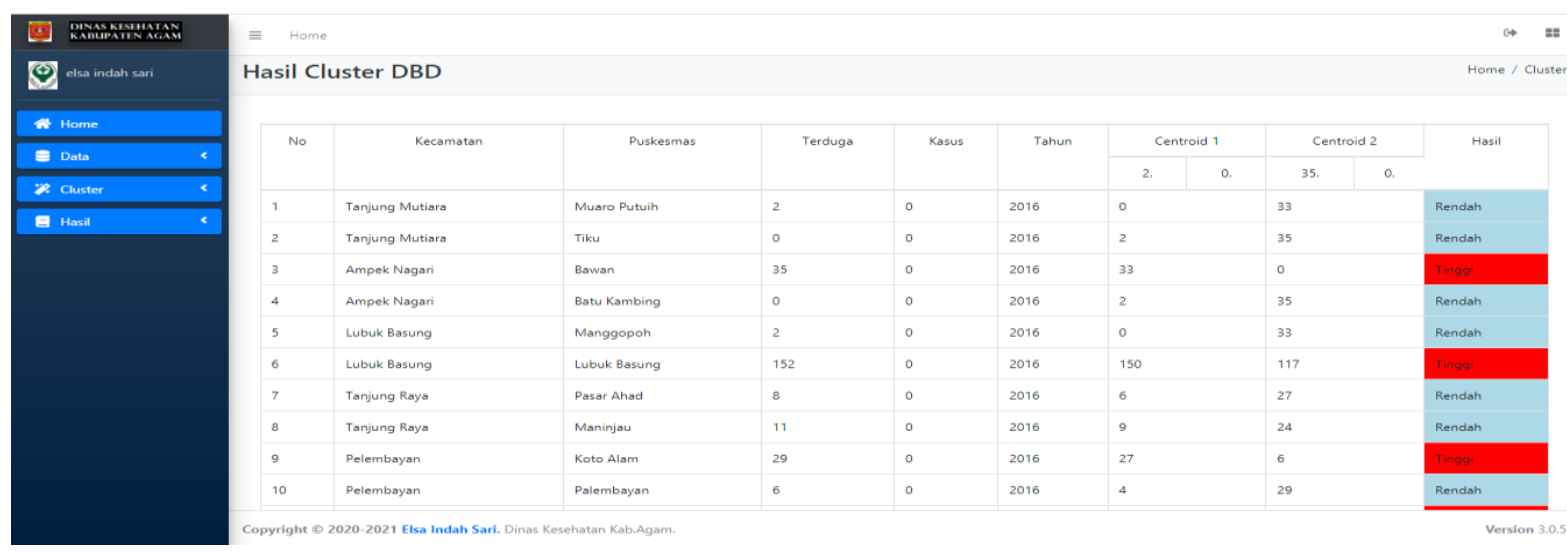

Gambar 6. Halaman Hasil Klasterisasi

Berikut proses klasterisasi untuk penyakit DBD menggunakan algoritma KMedoids secara manual.

a. Menentukan Jumlah klaster.

Jumlah klaster ditentukan menggunakan Metode Elbow, dengan menghitung Sum of Square Error (SSE) menggunakan persamaan 1. Hasil perhitungan SSE diperlihatkan pada gambar 7. Pada saat jumlah klaster $k=1$ menunjukkan SSE $=1645,52$. Saat jumlah klaster $k=2$ nilai $S S E=556,13$. Di sini tampak nilai SSE mengalami penurunan, sehingga garis pada grafik membentuk siku. Nilai SSE terlihat stabil pada saat $k=3$ sampai dengan $k=5$. Sehingga untuk penelitian ini menggunakan klaster $\mathrm{k}=2$.

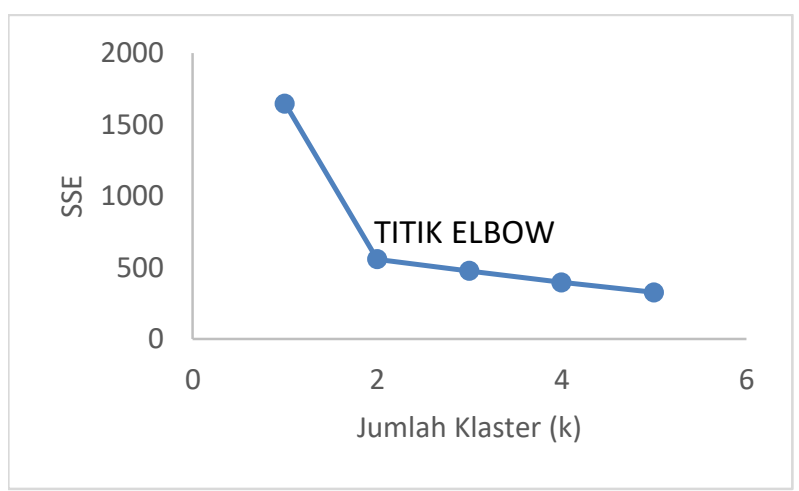

Gambar 7. Penentuan jumlah klaster terbaik dengan 368 data menggunakan Elbow avan. 
Di sini digunakan data kasus puskesmas Bawan dan Muaro Putuih tahun 2016. Data tersebut ditampilkan pada Tabel 2.

Tabel 2. Medoids Awal

\begin{tabular}{llll}
\hline Klaster & Puskesmas & Tahun & Kasus \\
\hline C1 & Bawan & 2016 & 35 \\
C2 & Muaro Putuih & 2016 & 2 \\
\hline
\end{tabular}

c. Menghitung jarak setiap data ke klaster terdekat menggunakan persamaan 2 .

Berikut merupakan contoh perhitungan jarak untuk masing-masing klaster:

Jarak dari semua data ke titik pusat klaster 1 (C1)

$$
\begin{aligned}
& C 1(1)=\sqrt{(28-35)^{2}}=7 \\
& C 1(2)=\sqrt{(9-35)^{2}}=26 \\
& C 1(3)=\sqrt{(6-35)^{2}}=29
\end{aligned}
$$

$$
\begin{aligned}
& C 1(91)=\sqrt{(0-35)^{2}}=35 \\
& C 1(92)=\sqrt{(2-35)^{2}}=33
\end{aligned}
$$

Jarak dari semua data ke titik pusat klaster 2 (C2)

$$
\begin{aligned}
& C 2(1)=\sqrt{(28-2)^{2}}=26 \\
& C 2(2)=\sqrt{(9-2)^{2}}=7 \\
& C 2(3)=\sqrt{(6-2)^{2}}=4 \\
& \ldots \ldots \ldots \ldots . . . \\
& \text { C2 } 2(91)=\sqrt{(0-2)^{2}}=2 \\
& C 2(92)=\sqrt{(2-2)^{2}}=0
\end{aligned}
$$

\begin{tabular}{|c|c|c|c|c|c|c|}
\hline \multirow[t]{2}{*}{ Puskesmas } & \multirow[t]{2}{*}{ Tahun } & \multirow[t]{2}{*}{ Kasus } & \multicolumn{2}{|c|}{ Jarak Centroid } & \multirow{2}{*}{$\begin{array}{r}\text { Jarak } \\
\text { Terdekat }\end{array}$} & \multirow[t]{2}{*}{ Klaster } \\
\hline & & & C1 & $\mathrm{C} 2$ & & \\
\hline Baso & 2019 & 28 & 7 & 26 & 7 & 1 \\
\hline Padang Tarok & 2019 & 9 & 26 & 7 & 7 & 2 \\
\hline Biaro & 2019 & 6 & 29 & 4 & 4 & 2 \\
\hline$\cdots \cdots$ & $\cdots \cdots$ & $\ldots \ldots$ & $\cdots \cdots$ & $\cdots \cdots$ & $\cdots \cdots$ & $\cdots \cdots$ \\
\hline Tiku & 2016 & 0 & 35 & 2 & 2 & 2 \\
\hline Muaro Putui & 2016 & 2 & 33 & 0 & 0 & 2 \\
\hline \multicolumn{2}{|c|}{ Jumlah } & & 2851 & 757 & & \\
\hline \multicolumn{2}{|c|}{ Total } & & \multicolumn{2}{|c|}{3608} & & \\
\hline
\end{tabular}

Setelah itu menentukan klaster untuk setiap data dengan melihat jarak terdekatnya, sehingga didapatkan hasil iterasi seperti pada Tabel 3.

Tabel 3. Hasil Iterasi Pertama

\begin{tabular}{|c|c|c|c|c|c|c|}
\hline \multirow[t]{2}{*}{ Puskesmas } & \multirow[t]{2}{*}{ Tahun } & \multirow[t]{2}{*}{ Kasus } & \multicolumn{2}{|c|}{ Jarak Centroid } & \multirow{2}{*}{$\begin{array}{c}\text { Jarak } \\
\text { Terdekat }\end{array}$} & \multirow[t]{2}{*}{ Klaster } \\
\hline & & & $\mathrm{C} 1$ & $\mathrm{C} 2$ & & \\
\hline Baso & 2019 & 28 & 23 & 24 & 23 & 1 \\
\hline Padang Tarok & 2019 & 9 & 2 & 5 & 4 & 1 \\
\hline Biaro & 2019 & 6 & 1 & 2 & 1 & 1 \\
\hline$\ldots$. & $\ldots$. & $\ldots$. & $\ldots$. & $\ldots$. & $\ldots$. & $\ldots$. \\
\hline$\ldots \ldots$ & $\ldots \ldots$ & $\ldots \ldots$ & $\ldots$. & $\ldots$. & $\ldots \ldots$ & $\ldots$. \\
\hline Tiku & 2016 & 0 & 5 & 4 & 4 & 2 \\
\hline
\end{tabular}

d. Menentukan pusat klaster baru secara acak (non medoid)

Tabel 4. Medoid baru
Selanjutnya melakukan proses perhitungan jarak setiap data ke pusat klaster seperti pada iterasi pertama. Hasil dapat dilihat pada Tabel 5.

\begin{tabular}{cccc}
\hline Klaster & Puskesmas & Tahun & Kasus \\
\hline C1 & $\begin{array}{c}\text { Lubuk } \\
\text { Basung }\end{array}$ & 2019 & 5 \\
C2 & $\begin{array}{c}\text { Manggopoh } \\
\text { Mangong }\end{array}$ & 4 \\
\hline
\end{tabular}

Tabel 5. Hasil Iterasi Kedua 


\begin{tabular}{cccccc} 
Muaro Putui & 2016 & 2 & 3 & 2 & 2 \\
\hline & Jumlah & 781 & 4117 \\
\hline Total & \multicolumn{5}{c}{5552} \\
\hline
\end{tabular}

e. Menghitung Total Simpangan

Langkah selanjutnya menghitung Total simpangan (S) yaitu selisih total cost baru dengan total cost lama. Total simpangan (S) dihitung menggunakan persamaan

$$
\begin{gathered}
S=\text { total cost baru }- \text { total cost lama } \\
S=5552-3608=1944
\end{gathered}
$$

karena $S>0$ maka iterasi berhenti. Sehingga didapatkan hasil klasterisasi penyakit DBD yaitu klaster tinggi terdiri dari 10 anggota dan klaster rendah terdiri dari 82 anggota. Anggota masing-masing klaster tinggi ditunjukkan pada tabel 6 dan klaster rendah pada tabel 7 .

\begin{tabular}{|c|c|c|c|}
\hline No & Puskesmas & Tahun & Kasus \\
\hline 1 & Baso & 2019 & 28 \\
\hline 2 & Maninjau & 2019 & 21 \\
\hline 3 & $\begin{array}{l}\text { Lubuk } \\
\text { Basung } \\
\text { Pakan }\end{array}$ & 2018 & 58 \\
\hline 4 & $\begin{array}{l}\text { Kamis } \\
\text { Lubuk }\end{array}$ & 2017 & 31 \\
\hline 5 & $\begin{array}{l}\text { Basung } \\
\text { Pakan }\end{array}$ & 2017 & 65 \\
\hline 6 & Kamis & 2016 & 78 \\
\hline 7 & Matur & 2016 & 41 \\
\hline 8 & Koto Alam & 2016 & 29 \\
\hline 9 & $\begin{array}{l}\text { Lubuk } \\
\text { Basung }\end{array}$ & 2016 & 152 \\
\hline 10 & Bawan & 2016 & 35 \\
\hline
\end{tabular}

Tabel 6. Anggota Klaster Tinggi ( C1)

Dari hasil klasterisasi data penyakit DBD di atas dapat dilihat yang termasuk dalam kelompok rendah dengan rata-rata jumlah kasus di bawah 20, sedangkan kelompok tinggi di atas 20 kasus.

Selain penyakit DBD, langkah di atas dilakukan juga untuk klasterisasi penyakit tuberculosis dan pneumonia.

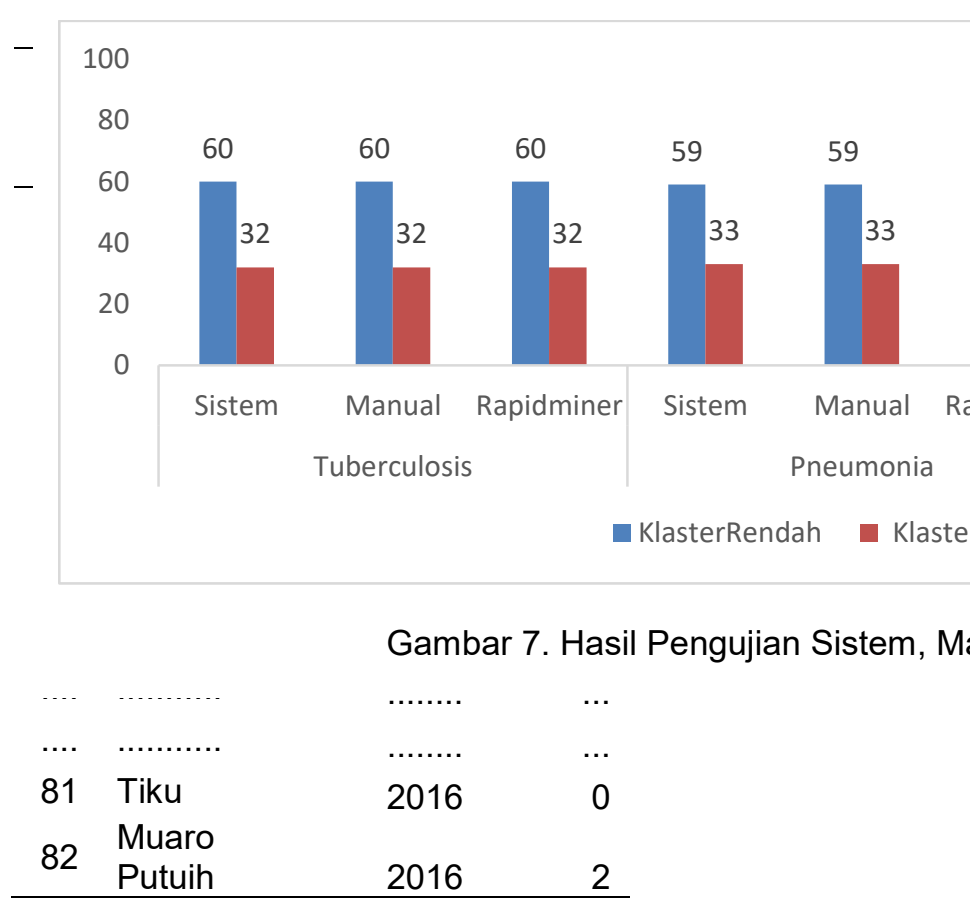

\section{Pengujian}

Untuk menguji kinerja sistem maka dilakukan dengan cara membandingkan hasil klasterisasi menggunakan perhitungan manual dan aplikasi Rapidminer. Dari gambar 7 menunjukkan hasil klaster yang sama. Ini menunjukkan sistem sudah bekerja dengan baik. 


\section{KESIMPULAN}

Berdasarkan penelitian ini dapat disimpulkan bahwa klasterisasi penyakit menggunakan algoritma K-Medoids telah diterapkan pada sistem yang dirancang dengan 2 (dua) klaster yaitu rendah dan tinggi. Hasil pengujian diperoleh anggota masing-masing klaster untuk tiap-tiap penyakit yaitu tuberculosis klaster tinggi 32 dan rendah 60 , penyakit pneumonia klaster tinggi 33 dan rendah 59, sedangkan untuk penyakit DBD klaster tinggi 10 anggota dan rendah 82 anggota. Hasil yang sama diperoleh dengan pengujian menggunakan perhitungan manual dan aplikasi Rapidminer. Ini menunjukkan bahwa sistem telah bekerja dengan baik.

Saran untuk penelitian selanjutnya dapat dikembangkan dengan menambahkan jenis penyakit, jumlah klaster, dan atribut lain padanya di Dinas Kesehatan Kabupaten Agam

\section{REFERENSI}

[1] Dinas Kesehatan, Profil Kesehatan Kabupaten Agam Tahun 2018. Kab.Agam, 2018.

[2] Suyanto, Data Mining untuk Klasifikasi dan Klasterisasi Data. Bandung: Informatika Bandung, 2017.

[3] G. Gustientiedina, M. H. Adiya, and Y. Desnelita, "Penerapan Algoritma KMeans Untuk Clustering Data ObatObatan," J. Nas. Teknol. dan Sist. Inf., vol. 5, no. 1, pp. 17-24, 2019, doi: 10.25077/teknosi.v5i1.2019.17-24.

[4] J. Han, M. Kamber, and J. Pei, "Data mining concepts and techniques third edition," Morgan Kaufmann Ser. Data Manag. Syst., vol. 5, no. 4, pp. 83-124, 2011.

[5]

$\begin{array}{lr}\text { B. Riyanto, } & \text { "PENERAPAN } \\ \text { ALGORITMA } & \text { K-MEDOIDS } \\ \text { CLUSTERING } & \text { UNTUK } \\ \text { PENGELOMPOKKAN } & \text { PENYEBARAN } \\ \text { DIARE DI KOTA MEDAN ( STUDI } \\ \text { KASUS: KANTOR } & \text { DINAS } \\ \text { KESEHATAN KOTA MEDAN )," vol. 3, }\end{array}$

pp. 562-568, 2019, doi: 10.30865/komik.v3i1.1659.

[6] K. Khomsatun, D. Ikhsan, M. Ali, and K. Kursini, "SISTEM PENGAMBILAN KEPUTUSAN PEMILIHAN LAHAN TANAM DI KABUPATEN WONOSOBO DENGAN K-MEANS CLUSTERING DAN TOPSIS," J. Nas. Pendidik. Tek. Inform. JANAPATI, vol. 9, no. 1, pp. 55-62, 2020.

[7] L. P. Rizby, Marji, and L. Muflikhah, "Clustering Pasien Kanker Berdasarkan Struktur Protein Dalam Tubuh," J. Pengemb. Teknol. Inf. dan IImu Komput. Univ. Brawijaya, vol. 2, no. 10, pp. 3810-3816, 2018.

[8] I. Kamila, U. Khairunnisa, and M. Mustakim, "Perbandingan Algoritma KMeans dan K-Medoids untuk Pengelompokan Data Transaksi Bongkar Muat di Provinsi Riau," J. IIm. Rekayasa dan Manaj. Sist. Inf., vol. 5, no. 1 , p. 119, 2019, doi: 10.24014/rmsi.v5i1.7381.

[9] A. D. Andini, T. Arifin, A. R. Sanjaya, A. R. Sanjaya, S. Coefficient, and P. Pasien, "IMPLEMENTASI ALGORITMA K-MEDOIDS UNTUK KLASTERISASI DATA PENYAKIT PASIEN," vol. 2, no. 2, pp. 128-138, 2020.

[10] L. Purba, S. Saifullah, and R. Dewi, "Pengelompokan Kasus Penyakit Aids Berdasarkan Provinsi Dengan Data Mining K-Medoids Clustering," KOMIK (Konferensi Nas. Teknol. Inf. dan Komputer), vol. 3, no. 1, pp. 687-694, 2019, doi: 10.30865/komik.v3i1.1679.

[11] T. Juninda and E. Andri, "Penerapan Algoritma K-Medoids untuk Pengelompokan Penyakit di Pekanbaru Riau," no. November, pp. 42-49, 2019.

[12] S. Sundari, I. S. Damanik, A. P. Windarto, H. S. Tambunan, J. Jalaluddin, and A. Wanto, "Analisis KMedoids Clustering Dalam Pengelompokkan Data Imunisasi Campak Balita di Indonesia," Pros. Semin. Nas. Ris. Inf. Sci., vol. 1, no. September, p. 687, 2019, doi: 10.30645/senaris.v1i0.75. 
[13] H. Ningrum, E. Irawan, and M. R. Lubis, "Implementasi Metode KMedoids Clustering Dalam Pengelompokan Data Penyakit Alergi Pada Anak," Jurasik (Jurnal Ris. Sist. Inf. dan Tek. Inform., vol. 6, no. 1, pp. 130-139, 2021.

[14] S. Sindi, W. R. O. Ningse, I. A. Sihombing, F. I. R. H. Zer, and D. Hartama, "Analisis algoritma k-medoids clustering dalam pengelompokan penyebaran covid-19 di indonesia," JurTI (Jurnal Teknol. Informasi), vol. 4, no. 1, pp. 166-173, 2020.

[15] E. Irwansyah, E. S. Pratama, and M. Ohyver, "Clustering of Cardiovascular Disease Patients Using Data Mining Techniques with Principal Component Analysis and K-Medoids," 2020.

[16] D. Marlina, A. Fernando, and A. Ramadhan, "Implementasi Algoritma KMedoids dan K-Means untuk Pengelompokkan Wilayah Sebaran Cacat pada Anak," J. CorelT J. Has. Penelit. IImu Komput. dan Teknol. Inf., vol. 4, no. 2, pp. 64-71, 2018.

[17] H. Kusumah, M. R. Lubis, and H. S. Tambunan, "Penerapan Algoritma KMedoids Dalam Pengelompokan Imunisasi Lanjutan Pada Anak Usia 2 Tahun," Resolusi Rekayasa Tek. Inform. dan Inf., vol. 1, no. 4, pp. 265273, 2021.

[18] D. A. I. C. Dewi and D. A. K. Pramita, "Analisis Perbandingan Metode Elbow dan Silhouette pada Algoritma Clustering K-Medoids dalam Pengelompokan Produksi Kerajinan Bali," Matrix J. Manaj. Teknol. dan Inform., vol. 9, no. 3, pp. 102-109, 2019. 